\title{
Lung cancer epigenetics: emerging biomarkers
}

Lung cancer is the leading cause of cancer-related deaths worldwide, and the 5-year survival rate is still very poor due to the scarcity of effective tools for early detection. The discovery of highly sensitive and specific biomarkers highlighting pathological changes early enough to allow clinical intervention is therefore of great importance. In the last decade, epigenetics and particularly research on DNA methylation have provided important information towards a better understanding of lung cancer pathogenesis. Novel and promising molecular biomarkers for diagnosis and prognosis of lung cancer are continuously emerging in this area, requiring further evaluation. This process includes extensive validation in prospective clinical trials before they can be routinely used in a clinical setting. This review summarizes the evidence on epigenetic biomarkers for lung cancer, focusing on DNA methylation.

\section{KEYWORDS: cell-free circulating DNA diagnosis DNA methylation non-small-cell lung cancer prognosis tumor biomarkers}

Lung cancer is the most common malignancy affecting both genders and remains the main cause of cancer-related deaths worldwide [1]. Only $13 \%$ of lung cancer patients survive more than 5 years. Lung cancers are classified according to histological types and this classification has important implications for the clinical management and prognosis of the disease. There are two main histological groups of lung cancer, non-small-cell lung cancer (NSCLC) and small-cell lung cancer; approximately $85 \%$ of lung tumors are NSCLC, which comprise three major histological subtypes: adenocarcinoma, squamous cell carcinoma and large-cell carcinoma [2].

Initiation and progression of lung carcinoma is the result of the interaction between genetic, epigenetic and environmental factors. In lung cancer, epigenetic alterations such as promoter DNA methylation that leads to gene silencing are common events. These alterations can take place in defined nuclear positions and chromosome domains after exposure to environmental risk factors such as smoking, drugs and chronic inflammation [3]. Epidemiological studies indicate that cigarette smoking has a strong association [4], since approximately $80-90 \%$ of lung cancers are attributable to cigarette smoking [5]. Although the majority of lung cancer patients are smokers, only a minority of lifetime smokers will develop the disease. This strongly indicates that genetic and/or epigenetic susceptibility plays a causal role in lung carcinogenesis [6].
Early detection of lung carcinoma could change the disease outcome; in fact, the survival rate can increase dramatically. In the effort to improve early detection, many imaging and cytology-based strategies have been employed; however, none has yet been highly effective, either because of limited sensitivity or the prohibitive cost they bear to public health systems [7,8]. A report on detection of early-stage cancers using low-dose spiral (helical) computed tomography (CT) described a 10-year survival rate of $88 \%$ [7]. The recent low-dose spiral CT protocols can be very efficient in detecting small tumors [9,10]; however, the number of indeterminate nodules is high, posing questions on the appropriate management of these patients [11]. It is now widely accepted that epidemiological risk modeling is required for stratification of individuals for CT screening [12]. In addition, one of the major unmet clinical needs is the inclusion of new molecular biomarkers on nonor minimally invasive samples to assist early diagnosis, prognosis and prediction of response to treatment.

Understanding the molecular pathways within lung cancer, and focusing on their molecular heterogeneity, is the most effective way towards the development of novel diagnostic and therapeutic tools. In the last decade, a plethora of molecular factors all involved in lung carcinogenesis have been evaluated as prognostic biomarkers, such as markers of apoptosis (BCL-2), cellular adhesion
Ioanna Balgkouranidou', Triantafillos Liloglou ${ }^{2}$ \&. Evi S Lianidou*1 2Laboratory of Analytical Chemistry, Department of Chemistry, University of Athens, 15771 Athens, Greece 'University of Liverpool, Institute of Translational Medicine, Department of Molecular \& Clinical Cancer Medicine, Liverpool, UK *Author for correspondence: Tel.: +30 2107274319 Fax: +302107274750 lianidou@chem.uoa.g

\section{Future Medicine partor}


and cellular growth (RAS, EGF receptor) and tumor proliferation [13]. The recent advances in the field of lung cancer epigenetics provide a very promising step towards the direction of novel biomarker development. Epigenetics refer to altered phenotypes (e.g., patterns of gene expression) mediated by changes other than an alteration in the primary nucleotide sequence. Such epigenetic changes are DNA methylation, miRNAs, nucleosome remodeling and covalent histone modifications [14].

This review summarizes the emerging epigenetic biomarkers in lung cancer, focusing on DNA methylation and their potential clinical applications in lung cancer.

\section{Tumor biomarkers}

The National Cancer Institute defines a biomarker as a biological molecule found in blood, other body fluids or tissues that is a sign of a normal or abnormal process or of a condition or disease. Tumor biomarkers offer good guidance on many areas of cancer biology. They are not only useful in early diagnosis of cancer but can also provide important prognostic information, forecasting how aggressive the disease process is and distinguish the tumor's outcome [15]. Another important application is to predict the response to therapy; predictive biomarkers evaluate the probable benefit of a particular treatment. The clinical information given by tumor biomarkers is significant in the selection of appropriate treatment, leading to personalized cancer therapy [16]. There are several distinct types of tumor biomarkers based on different areas: genetics, epigenetics, proteomics, metabolomics and imaging technology.

\section{DNA methylation as a tumor biomarker}

Epigenetic abnormalities are present in all human cancers and are currently considered to be the hallmark of cancer initiation and progression. There is increasing information on the extent of epigenetic reprogramming of cancer cells, utilizing high-throughput methodology, such as microarrays and nextgeneration sequencing. Currently, the beststudied epigenetic event in the mammalian genome is DNA methylation, which is a chemical covalent modification of cytosine. In particular, is the addition of a methyl group $\left(\mathrm{CH}_{3}\right)$ at the fifth carbon position of cytosine bases that are located $5^{\prime}$ to a guanosine in a CPG dinucleotide. The distribution of $\mathrm{CpG}$ dinucleotides in the genome is uneven and $\mathrm{CpG}$ dinucleotides are found to be concentrated in short regions called $\mathrm{CpG}$ islands (CGIs). Although CGIs comprise less than $1 \%$ of the genome, they are most frequently located in gene promoter regions and are generally unmethylated in normal adult cells. Increased methylation (hypermethylation) in the promoter region of a gene leads to reduced expression, whereas methylation in the transcribed region (gene body) has a variable effect on gene expression $[17,18]$.

Cancer cells have an aberrant methylation signature; they present global hypomethylation [19] and hypermethylation of tumor suppressor genes (TSGs) [18-20]. Global hypomethylation is frequent in NSCLC and is associated with genomic instability [21] and aberrant overexpression of oncogenic gene isoforms [22]. A large number of aberrantly methylated genes have also been identified in lung cancer, either by high-throughput methods [23-35] or target-based approaches [36-38]. Furthermore, methylation has been described as an early event in lung tumorigenesis. A well-studied example of early hypermethylation is that of $p 16$, contributing significantly to its transcriptional silencing [39-41]. Additional examples include $\mathrm{H}$-cadherin [42], RASSF1A [43], APC [44,45] and $D A P K 1$ [46]. This plethora of high-throughput and gene-focused approaches has now provided a very long list of candidate markers for lung cancer diagnosis and prognosis, and predictive information.

The virtually universal presence of DNA hypermethylation in all types of cancer makes it an ideal candidate tumor biomarker. Compared with other molecular marker classes such as mRNA and proteins, DNA methylation has many advantages [47]. First, DNA methylation is a covalent modification of DNA, so it is chemically stable and can survive harsh conditions for long periods of time. Second, through simple procedures it can be readily amplifiable and easily detectable. In addition, contrary to cancer-specific mutations, which are relatively rare and present in different gene positions, the incidence of aberrant methylation of specific CGIs is much higher [48-50], and moreover such methylation can be discovered by genome-wide screening procedures [51,52]. Methylation-specific PCR has been extensively used to detect aberrant methylation even in cases where methylated sequences are rare [53]. Methylation can be a very early indication of neoplastic transformation, since it has been observed even in early stages 
of carcinogenesis and in non-neoplastic tissues. For example, methylation of noncore regions of p16 is observed in pulmonary hyperplasia $(17 \%)$, dysplasia (24\%) and lung carcinoma in situ (50\%) [39,54]. DNA methylation usually affects longer DNA areas within promoters as opposed to point mutations that affect a single nucleotide and could variably occur along the gene sequence. Therefore, methylation profiling is less laborious and less expensive than mutation profiling.

Recent advantages in DNA methylation detection techniques include powerful tools such as sodium bisulfite (SB) conversion, restriction genomic scanning and CGI microarrays [55]. SB conversion by itself is not a DNA methylation detection technique, but just the first step for some of the assays listed, such as methylation-specific PCR. CGI methylation can distinguish the normal and aberrant patterns of methylation, since following SB treatment, 'converted' DNA can be used in many PCR-based techniques. A routine DNA methylation diagnostic tool has to be sensitive and reproducible, with fast and standardized protocols able to facilitate automation [56]. Currently, quantitative methylation-specific PCR (qMSP) seems to hold many of these characteristics and has demonstrated very good performance in clinical samples such as bronchial washings [57] and plasma [58]. However, significant development is required for these assays to reach good clinical laboratory practice standards [59].

Aberrant DNA methylation can be applied to cancer diagnostics in three different levels of clinical management. First, aberrant methylation specifically present in cancer cells can be used in diagnosing cancer cells in biopsies or body fluids, that is, detecting cell-free DNA (cfDNA) circulating in plasma. Second, aberrant methylation at certain CGIs is associated with disease phenotype(s), such as histological type, degree of differentiation, aggressive behavior, response to chemotherapy regimens or association with adverse drug effects; it can be used as a prognostic or predictive marker in managing treatment and follow-up of diagnosed cases. Third, if aberrant methylation of some CGIs in noncancerous tissues is associated with a risk for cancer development, it can be used as a cancer risk marker.

Currently, DNA methylation appears as one of the most promising epigenetic biomarkers, which can improve the early detection of cancer and subsequent management of patients with diagnosed malignancy. However, how simple is the development of a biomarker? How far are we from the clinical validation of methylation biomarkers? Recently the DNA methylation profile distinguishing epithelial-like from mesenchymal-like NSCLC, which display different response to anti-EGFR therapy, was studied [60]. For this purpose, a genome-wide analysis was first performed in epithelial- and mesenchymal-like NSCLC cell lines [60]. The most discriminating differentially methylated regions classified the cell lines as epithelial or mesenchymal and the methylation data were validated by direct sequencing of cloned fragments. When qMSP assays were performed on the 13 most discriminative genes, ten out of the 13 genes were able to classify cell lines, while seven of them were associated with in vitro erlotinib resistance [60]. When the methylation status of ERB2 and ZEB2 was more precisely investigated by pyrosequencing and qMSP in NSCLC cell lines, primary tumors and biopsies of patients resistant to chemotherapy, it was shown to be predictive of an epithelial-like phenotype and could be further used for diagnostic purposes [60].

To facilitate similar procedures for the discovery and validation of DNA methylation-based biomarkers, computational methods for optimized biomarkers selection, evaluation of performance and assay design must be developed [61]. At this point, the necessity of longitudinal retrospective studies should be underlined. Prior to attempting to develop assays for routine clinical use, these preliminary findings must be confirmed in studies with high statistical power.

DNA methylation has been detected in a number of body fluids of patients with cancer. In some tumor types this may be an alternative to tissue biopsy or paraffin-embedded tissues. These samples may provide a less invasive approach for disease detection and monitoring compared with tissues. In lung cancer, aberrant DNA methylation can be detected in the sputum of patients [62,63], in bronchoalveolar lavage [64-66] and saliva [67,68]. It has been suggested that this may also play a role in early detection and assessment of lung cancer risk. Methylation of the $p 16$ and $M G M T$ genes has been detected in the sputum up to 3 years prior to diagnosis of squamous cell carcinoma [41]. Interestingly, DNA methylation has been reported in exhaled breath from lung cancer patients [69]. 


\section{Circulating tumor DNA}

Over the last decade, there has been a significant boost in blood-based DNA methylation assays in clinical research, as it is a potential source of minimally invasive samples, mainly targeting cfDNA in serum or plasma [70-72], or DNA extracted from peripheral blood leucocytes [73], and since it has become clear that hypermethylation can be detected in tumorderived DNA circulating in plasma or serum of cancer patients. The precise mechanism by which DNA is released into the bloodstream still remains uncertain. Among the hypotheses explaining the presence of cfDNA in plasma or serum, active release of tumor DNA and passive DNA leakage following necrosis or apoptosis of neoplastic cells are discussed [74]. In a very recent study, a connection between cfDNA and circulating tumor cells from the same patients has been reported for the first time, based on the methylation status of SOX17 [75]. cfDNA maintains the genetic and epigenetic profile of its primary tumor source [76,77]. It must be noted that cfDNA from plasma is not identical to cfDNA isolated from serum; the most obvious difference is the higher levels of cfDNA in serum than in plasma. Apparently, additional DNA in serum is associated with the clotting process $[78,79]$. Lower concentrations of cfDNA in plasma compared with serum better reflect cfDNA in circulation and also the disease [80,81]. A plethora of loci have been reported to be methylated in the plasma/serum of NSCLC patients suggesting novel potential diagnostic and prognostic targets. Kneip et al. have recently reported that DNA methylation of $S H O X 2$ could be used as a biomarker to distinguish between malignant lung disease and controls at a sensitivity of $60 \%$ and a specificity of $90 \%$ [82]. Cancer in patients with stage II (72\%), III (55\%) and IV (83\%) disease were detected at a higher sensitivity when compared with stage I patients. Smallcell lung cancer and squamous cell carcinoma were detected at the highest sensitivity when compared with adenocarcinomas. Based on this study, SHOX2 DNA methylation could be used as a biomarker for detecting the presence of malignant lung disease in blood plasma from patients with lung cancer [82]. In a recent study, Begum et al. tested the methylation status of six genes (APC, CDH1, MGMT, DCC, RASSF1A and AIM1) in serum of a limited number of lung cancer patients for elucidation of the diagnostic application of this panel of markers [45]. Their results indicate that DCC has $100 \%$ specificity, and $35.5 \%$ of the 76 lung cancer patients were correctly identified. However, this approach needs to be evaluated in a larger test set to determine the role of this gene set in early detection and surveillance of lung cancer [45]. Several studies have examined DNA methylation in the primary tumor and corresponding plasma/serum and in most cases methylation in blood was only seen in patients with methylated primary tumor DNA [83]. The development of a blood-based test for lung cancer based on gene promoter methylation could augment current early detection approaches such as CT scans and sputum cytology. The methylation markers of lung cancer show great potential in molecular detection approaches. As was very clearly shown, these markers can be detected in the plasma of stage I lung cancer patients and therefore show promise in the early detection of lung cancer [58]. However, it is still very difficult to find these methylation events in serum DNA with a high enough degree of sensitivity and specificity. For this reason, quantitative and reliable estimation of DNA methylation levels for multiple genomic regions pose a major challenge where starting DNA is available in very low quantity, as in plasma or serum samples. Major advances in the development of techniques for the quantitative detection of DNA methylation in a minute amount of DNA, particularly valuable in profiling a large sample series of body fluids from molecular epidemiology studies, were recently reviewed [84]. With currently available methods for the simultaneous detection of methylation, up to 28,000 CGIs can be analyzed. Overall, we are just at the beginning of translating these findings into the clinic and there is hope that future patients will benefit from these results [84]. However, we do not want to overestimate the applicability of methylation tests for diagnosing cancer in serum or plasmaderived DNA; unless follow-up in larger cohorts is available, such evidence remains anecdotal.

\section{DNA methylation as a tumor biomarker in lung cancer - Early detection}

A diagnostic molecular biomarker would ideally reflect early steps in cancer development. It thus needs to be able to discriminate between neoplastic transformation and preneoplasia. A variety of epigenetic biomarkers have been evaluated so far in lung cancer diagnostics. 
The promoter of $p 16$ was probably the first to be shown hypermethylated early in lung carcinogenesis [54,85] and a number of studies followed showing abnormal hypermethylation of many gene promoters such as $A P C, R A R b$, NeuroD, RASSF1 and MGMT [86-91]. Recently, the diagnostic value of RASSF1A methylation and $K R A S$ mutations in bronchial washings reported a $29 \%$ efficiency of detecting malignancy in false-negative or ambiguous cytology outcomes [92]. SHOX2 quantified methylation showed promising results in bronchial aspirates, with a sensitivity of $78 \%$ and a specificity of $96 \%$ [93] while SHOX2 sensitivity and specificity in plasma was 60 and $90 \%$, respectively [82]. A group of genes $(A P C$, RASSF1A, KLK10, CDH13 and DLEC1), when tested in plasma, demonstrated $84 \%$ sensitivity and $74 \%$ specificity (TABLE 1 ).

\section{- Prognosis \& prediction}

Conventionally, tumor characteristics such as pathological subtype, nodal invasion and metastasis are used to predict disease outcome. In addition to these traditional prognostic factors, aberrant DNA methylation could refine prognostic information [94]. Brock et al. found aberrant patterns of promoter methylation of $A P C, R A S S F 1 A, p 16$ and $C D H 13$ associated with early recurrence in stage I NSCLC [95]. In support of this notion, Yamamoto et al. indicated that synchronous methylation of $\mathrm{CDH} 13$ and p16 is a more effective prognostic biomarker than $p 16$ alone [96]. Hypermethylation of TSGs is mostly associated with worst outcome. Zhang et al. explored the methylation status of 15 genes by methylation-specific PCR in 64 paired NSCLC and adjacent normal tissues [97]. The authors found that patients with a simultaneous methylation of four or more genes had poorer 2-year progression-free survival [97]. Recently, promoter methylation of BRMS1 was shown to correlate with smoking history and poor survival in NSCLC [98]. Similarly, DNA methylation on ten genes has been reported to predict survival of stage I NSCLC patients [99] while $S H O X 2$, analyzed in 474 paraffinembedded samples from NSCLC patients, also seems to contribute in predicting disease outcome (Table 2) [100].

\section{Methylation of miRNA loci as novel biomarkers in lung cancer}

miRNAs are considered novel epigenetic regulators of gene expression, playing important roles in various biological processes such as development, proliferation, cellular differentiation and apoptosis, through silencing of specific target genes [101-105]. Changes in miRNA expression levels have been detected in many human tumor types and recent studies have demonstrated their critical role in cancer pathogenesis [106-108]. Numerous recent studies indicated that miRNAs may function as TSGs or oncogenes [109]. Investigating the expression patterns and functions of miRNAs in lung cancer is still at an early stage, although some of them, such as let-7 and miR-128b, are known to be aberrantly expressed in lung carcinoma. let-7, a well-understood example since it is one of the first identified miRNAs, seems to function as a tumor suppressor in lung cancer [110]. Overexpression of this miRNA may inhibit the expression of Ras [111] and repress proliferation of lung cancer cells [112] while overexpression of miR-206 can inhibit migration and invasion of lung cancer cells [113]. Let-7a3 and miR-17-92 are oncogenic miRNAs, and are upregulated in lung cancer cells [114].

DNA methylation has been shown to affect the expression levels of miRNAs [115], while miRNAs can be regulators as well as targets of DNA methylation. Through aberrant DNA methylation miRNAs can be activated or silenced [116-118]. When let-7-a3 is hypomethylated it is overexpressed in lung cancer

Table 1. DNA methylation as a diagnostic marker in non-small-cell lung cancer.

\begin{tabular}{|c|c|c|c|}
\hline Study (year) & Gene & Tissue/body fluid & Ref. \\
\hline $\begin{array}{l}\text { Belinsky et al. } \\
\text { (1998) }\end{array}$ & p16(INK4a) & Biopsy samples, sputum & [39] \\
\hline $\begin{array}{l}\text { Topaloglu et al. } \\
\text { (2004) }\end{array}$ & $\begin{array}{l}\text { FHIT, H-cadherin RAR } \beta, \\
C D H 1, A P C\end{array}$ & Bronchial lavage & [87] \\
\hline $\begin{array}{l}\text { Geng et al. } \\
(2012)\end{array}$ & NEUROG2, NID2 & Lung tumor tissue & [88] \\
\hline $\begin{array}{l}\text { Schiemann et al. } \\
\text { (2005) }\end{array}$ & $\begin{array}{l}\text { MGMT, RASSF1A, } \\
\text { GSTP1, CDKN2A, } \\
\text { RARB2, ARF, APC }\end{array}$ & Bronchial aspirates & [89] \\
\hline $\begin{array}{l}\text { Grote et al. } \\
(2006)\end{array}$ & $\begin{array}{l}\text { CDKN2A, RARß2, } \\
\text { RASSF1A }\end{array}$ & Bronchial aspirates & [90] \\
\hline $\begin{array}{l}\text { Fujii et al. } \\
(2012)\end{array}$ & $\begin{array}{l}\text { RASSF1A, p16INK4a, } \\
\text { RARB, MGMT, DAPK }\end{array}$ & Pleural fluid & [91] \\
\hline $\begin{array}{l}\text { Van der Drift et al. } \\
\text { (2012) }\end{array}$ & RASSF1A & Bronchial washings & [92] \\
\hline $\begin{array}{l}\text { Schmidt et al. } \\
\text { (2010) }\end{array}$ & CDKN2A, RARB, SHOX2 & Primary NSCLC tumor & [93] \\
\hline $\begin{array}{l}\text { Kneip et al. } \\
\text { (2011) }\end{array}$ & SHOX2 & Plasma & [82] \\
\hline
\end{tabular}


Table 2. DNA methylation as a prognostic marker in non-small-cell lung cancer.

\begin{tabular}{|c|c|c|c|}
\hline Study (year) & Gene & Tissue/body fluid & Ref. \\
\hline $\begin{array}{l}\text { Brock et al. } \\
(2008)\end{array}$ & $\begin{array}{l}\text { MGMT, ASC, DAPK, } \\
\text { APC, RASSF1A, p16, } \\
\text { CDH13 }\end{array}$ & Paraffin-embedded tumor tissue & {$[95]$} \\
\hline $\begin{array}{l}\text { Yamamoto et al. } \\
\text { (2009) }\end{array}$ & $\begin{array}{l}\text { p16, RASSF1A, } \\
\text { CDH13 }\end{array}$ & Lung tumor tissue & {$[96]$} \\
\hline $\begin{array}{l}\text { Zhang et al. } \\
\text { (2011) }\end{array}$ & $\begin{array}{l}\text { RASSF1A, DAPK } \\
\text { RAR } 3, A P C \\
\text { CDH13, KLK10 } \\
\text { DLEC1, RASSF1A } \\
\text { SFRP1, RAR } \\
\text { CDKN2A }\end{array}$ & Primary NSCLC tumor/plasma & {$[97]$} \\
\hline $\begin{array}{l}\text { Yang et al. } \\
\text { (2011) }\end{array}$ & BRMS1 & Lung tumor tissue & {$[98]$} \\
\hline $\begin{array}{l}\text { Dietrich et al. } \\
(2012)\end{array}$ & PITX2, SHOX2 & Lung tumor tissue & {$[100]$} \\
\hline
\end{tabular}

cells, thus enhancing cancer phenotypes and oncogenic alterations [119]. In lung adenocarcinomas hypermethylation of $m i R-124 a$ mediates $\mathrm{Rb}$ phosphorylation and CDK6 activation [120], while the miRNA-29 family may restore aberrant methylation in lung cancer by targeting the 3 '-untranslated region of DNMT3A and $D N M T 3 B$, which are frequently upregulated in lung cancer and are associated with poor prognosis [120]. When miR-29 is overexpressed it can inhibit lung carcinogenesis by normalizing aberrant methylation in NSCLC through the induction of re-expression of methylated silenced TSGs [120]. Taken together, elucidating the relationship between DNA methylation and miRNAs will provide an improved understanding of the development of more complete tumor biomarkers.

\section{Future perspective}

DNA methylation represents one of the most important areas for the discovery of novel biomarkers for the diagnosis, prognosis and prediction of therapy. The frequency of DNA methylation aberrations in lung cancer and the technical advantages in detecting this modification in body fluids seems to provide an advantage over other types of biomarkers. However, despite the encouraging results obtained so far, significant challenges still lie ahead in this field. While the exact contribution of aberrant methylation to lung carcinogenesis and the mechanism underlying cancer-specific methylation alteration remain to be clarified, methodological issues have also to be solved. Technical procedures for different types of
DNA isolation (e.g., cfDNA from serum, total DNA from sputum) require standardization and analytical validation before any application in the clinical setting. For the vast majority of the suggested biomarkers, the data available is at the proof-of-principle level with inadequate retrospective validation. Finally, following the optimization of assays at good clinical laboratory practice standards, multicenter prospective validation is required to prove the immediate patient benefit and, in longer terms, cost-effectiveness for the public health system. It seems inevitable that in order to utilize the great potential of DNA methylation to provide specific and sensitive diagnostic tools for early detection of lung cancer, large multicenter consortia have to be formed to achieve the statistical power needed for clinical biomarker validation.

Moreover, the ever-growing number of genes that show epigenetic alterations in disease emphasizes the crucial role of these epigenetic alterations - particularly DNA methylation - for future diagnosis, prognosis and prediction of response to therapies [121]. It is crucial to note that epigenetic modifications such as DNA methylation are intrinsically reversible, in contrast with genetic mutations. This is a very promising approach towards the treatment of cancer patients via targeting epigenetic mechanisms. Intensive investigations have been performed to evaluate epigenetic drugs as novel therapeutic interventions. These DNA demethylating agents, used either alone or in combination with other agents such as chemotherapeutic drugs and histone deacetylase inhibitors, have been shown to be effective in treatment of cancer, although only in a small set of patients [122]. However in this case, we have to point out the potential risk of creating hypomethylation and the associated risks of genomic instability and activating epigenetically silenced oncogenes.

\section{Financial \& competing interests disclosure}

I Balgkouranidou is a recipient of a Hellenic Oncology Research Group Scholarship. T Liloglou's research is funded by the Roy Castle Lung Cancer Research Foundation, Cancer Research UK and the Royal Society. The authors have no other relevant affiliations or financial involvement with any organization or entity with a financial interest in or financial conflict with the subject matter or materials discussed in the manuscript apart from those disclosed.

No writing assistance was utilized in the production of this manuscript. 


\section{Executive summary}

\section{DNA methylation as a tumor biomarker}

- Epigenetic abnormalities are present in all human cancers and are currently considered to be the hallmark of cancer initiation and progression

- Currently, the best-studied epigenetic event in the mammalian genome is DNA methylation, which is a chemical covalent modification of cytosine.

- The virtually universal presence of DNA hypermethylation in all types of cancer makes it an ideal candidate tumor biomarker.

- DNA methylation is chemically stable, it can be readily amplifiable and is easy to detect.

- In lung cancer, aberrant DNA methylation can be detected in tissues, in plasma/serum, in sputum, in bronchial lavage and saliva.

\section{Circulating tumor DNA}

- Cell-free DNA maintains the genetic and epigenetic profile of its primary tumor source.

- A plethora of loci have been reported to be methylated in the plasma/serum of non-small-cell lung cancer (NSCLC) patients, suggesting novel potential diagnostic and prognostic targets such as APC, CDH1, MGMT, DCC, RASSF1A and others.

\section{DNA methylation as a tumor biomarker in lung cancer}

- A variety of epigenetic biomarkers have been evaluated so far in lung cancer diagnostics.

- The diagnostic value of RASSF1A methylation and KRAS mutations in bronchial washings reported a $29 \%$ efficiency of detecting malignancy in false-negative or ambiguous cytology outcomes.

- SHOX2 quantified methylation showed promising results in bronchial aspirates, with a sensitivity of $78 \%$ and a specificity of $96 \%$ while SHOX2 sensitivity and specificity in plasma was 60 and $90 \%$, respectively.

- Promoter methylation of APC, RASSF1A, p16 and CDH13 associated with early recurrence in stage 1 NSCLC.

- Promoter methylation of BRMS1 correlates with smoking history and poor survival in NSCLC.

\section{References}

Papers of special note have been highlighted as: "* of considerable interest

1 Molina JR, Yang P, Cassivi SD, Schild SE, Adjei AA. Non-small-cell lung cancer: epidemiology, risk factors, treatment, and survivorship. Mayo Clin. Proc. 83, 584-594 (2008).

2 Travis WD, Travis LB, Devesa SS. Lung cancer. Cancer 75, 191-202 (1995).

3 Baylin SB. The cancer epigenome: its origins, contributions to tumorigenesis, and translational implications. Proc. Am. Thorac. Soc. 9(2), 64-65 (2012).

4 Alberg AJ, Ford JG, Samet JM. Epidemiology of lung cancer ACCP evidence-based clinical practice guidelines (2nd Edition). Chest 132 (Suppl. 3), 29S-55S (2007).

5 Khuder SA. Effect of cigarette smoking on major histological types of lung cancer: a meta-analysis. Lung Cancer 31, 139-148 (2001).

6 Peto R, Darby S, Deo H, Silcocks P, Whitley E, Doll R. Smoking, smoking cessation, and lung cancer in the UK since 1950: combination of national statistics with case-control studies. Br. Med. J. 321, 323-329 (2000).

7 Henschke CI, Yankelevitz DF, Libby DM et al. Survival of patients with stage I lung cancer detected on CT screening. N. Engl. J. Med. 335, 1763-1771 (2006).

8 Schwartz AG, Prysak GM, Bock CH, Cote ML. The molecular epidemiology of lung cancer. Carcinogenesis 28, 507-518 (2007).
9 Markowitz SB, Miller A, Miller J et al. Ability of low-dose helical CT to distinguish between benign and malignant non calcified lung nodules. Chest 131(4), 1028-1034 (2007).

10 Baldwin DR, Duffy SW, Wald NJ, Page R, Hansell DM, Field JK. UK Lung Screen (UKLS) nodule management protocol: modelling of a single screen randomised controlled trial of low-dose CT screening for lung cancer. Thorax 66(4), 308-313 (2011).

11 Field JK, Smith RA, Aberle DR et al. IASLC CT screening workshop 2011 participants.

International association for the study of lung cancer computed tomography screening workshop 2011 report. J. Thorac. Oncol. 7(1), 10-19 (2012).

12 Raji OY, Duffy SW, Agbaje OF et al. Predictive accuracy of the Liverpool lung project risk model for stratifying patients for computed tomography screening for lung cancer: a casecontrol and cohort validation study. Ann. Intern. Med. 157(4), 242-250 (2012).

13 Coate LE, John T, Tsao MS, Shepherd FA. Molecular predictive and prognostic markers in non-small-cell lung cancer. Lancet Oncol. 10, 1001-1010 (2009).

14 Sharma S, Kelly TK, Jones PA. Epigenetics in cancer. Carcinogenesis 31(1), 27-36 (2010).

15 Kulasingam V, Diamandis EP. Strategies for discovering novel cancer biomarkers through utilization of emerging technologies. Nat. Clin. Pract. Oncol. 10, 588-599 (2008).

16 Duffy MJ. Role of tumor markers in patients with solid cancers: a critical review. Eur. J. Inern. Med. 18, 175-184 (2007).
17 Kerr KM, Galler JS, Hagen JA, Laird PW, Laird-Offringa IA. The role of DNA methylation in the development and progression of lung adenocarcinoma. Dis. Markers 23, 5-30 (2007).

18 Robertson KD. DNA methylation and human disease. Nat. Rev. Genet. 6, 597-610 (2005).

19 Feinberg AP, Tycko B. The history of cancer epigenetics. Nat. Rev. Cancer 4, 143-153 (2000).

20 Esteller M, Silva JM, Dominguez G et al. Promoter hypermathylation and BRCA1 inactivation in sporadic breast and ovarian tumors. J. Natl Cancer Inst. 92(7), 564-569 (2000).

21 Daskalos A, Logotheti S, Markopoulou S et al. Global DNA hypomethylation-induced $\Delta \mathrm{Np} 73$ transcriptional activation in nonsmall-cell lung cancer. Cancer Lett. 300 (1), 79-86 (2011).

22 Daskalos A, Nikolaidis G, Xinarianos G et al. Hypomethylation of retrotransposable elements correlates with genomic instability in non-small cell lung cancer. Int. J. Cancer 124(1), 81-87 (2009).

23 Carvalho RH, Haberle V, Hou J et al. Genome-wide DNA methylation profiling of non-small-cell lung carcinomas. Epigenetics Chromatin 5(1), 9 (2012).

24 Ehrich M, Nelson MR, Stanssens P et al. Quantitative high-throughput analysis of DNA methylation patterns by base-specific cleavage and mass spectrometry. Proc. Natl Acad. Sci. USA 102(44), 15785-15790 (2005). 
25 Ehrich M, Field JK, Liloglou T et al. Cytosine methylation profiles as a molecular marker in non-small cell lung cancer. Cancer Res. 66(22), 10911-10918 (2006).

26 Field JK, Liloglou T, Warrak S et al. Methylation discriminators in NSCLC identified by a microarray based approach. Int. J. Oncol. 27(1), 105-111 (2005).

27 Fukasawa M, Kimura M, Morita $S$ et al. Microarray analysis of promoter methylation in lung cancers. J. Hum. Genet. 51(4), 368-374 (2006).

28 Hatada I, Fukasawa M, Kimura M et al. Genome-wide profiling of promoter methylation in human. Oncogene 25(21), 3059-3064 (2006).

29 Lewin J, Plum A, Hildmann T et al. Comparative DNA methylation analysis in normal and tumour tissues and in cancer cell lines using differential methylation hybridisation. Int. J. Biochem. Cell Biol. 39(7-8), 1539-1550 (2007).

30 Nelson HH, Marsit CJ, Christensen BC et al. Key epigenetic changes associated with lung cancer development: results from dense methylation array profiling. Epigenetics 7(6), 559-566 (2012).

31 Rauch T, Li H, Wu X, Pfeifer GP. MIRAassisted microarray analysis, a new technology for the determination of DNA methylation patterns, identifies frequent methylation of homeodomain-containing genes in lung cancer cells. Cancer Res. 66(16), 7939-7947 (2006).

32 Selamat SA, Chung BS, Girard L et al. Genome-scale analysis of DNA methylation in lung adenocarcinoma and integration with mRNA expression. Genome Res. 22(7), 197-211 (2012).

33 Shames DS, Girard L, Gao B et al. A genome-wide screen for promoter methylation in lung cancer identifies novel methylation markers for multiple malignancies. PLoS Med. 3(12), e486 (2006).

34 Son JW, Jeong KJ, Jean WS et al. Genomewide combination profiling of DNA copy number and methylation for deciphering biomarkers in non-small cell lung cancer patients. Cancer Lett. 311(1), 29-37 (2011).

35 Wang Y, Zhang D, Zheng W, Luo J, Bai Y, Lu Z. Multiple gene methylation of nonsmall-cell lung cancers evaluated with 3-dimensional microarray. Cancer 112(6), 1325-1336 9 (2008).

36 Knight LJ, Burrage J, Bujac SR et al. Epigenetic silencing of the endothelin-B receptor gene in non-small-cell lung cancer. Int. J. Oncol. 34(2), 465-471 (2009).

37 Verri C, Roz L, Conte D et al.; EUELC Consortium. Fragile histidine triad gene inactivation in lung cancer: the European Early Lung Cancer project. Am. J. Respir. Crit. Care Med. 179(5), 396-401 (2009).

38 Xinarianos G, McRonald FE, Risk JM et al. Frequent genetic and epigenetic abnormalities contribute to the deregulation of cytoglobin in non-small-cell lung cancer. Hum. Mol. Genet. 15(13), 2038-2044 (2006).

39 Belinsky SA, Nikuja KJ, Palmisano WA et al. Aberrant methylation of p16(INK4a) is an early event in lung cancer and a potential biomarker for early diagnosis. Proc. Natl Acad. Sci. USA 95, 11891-11896 (1998).

40 Nuovo GJ, Plaia TW, Belinsky SA, Baylin $\mathrm{SB}$, Herman JG. In situ detection of the hypermethylation-induced inactivation of the p16 gene as an early event in oncogenesis. Proc. Natl Acad. Sci. USA 96, 12754-12759 (1999).

41 Palmisano WA, Divine KK, Saccomanno G et al. Predicting lung cancer by detecting aberrant promoter methylation in sputum. Cancer Res. 60, 5954-5968 (2000).

42 Kim DS, Kim MJ, Lee JY, Kim YZ, Park JY. Aberrant methylation of E-cadherin and $\mathrm{H}$-cadherin genes in non-small-cell lung cancer and its relation to clinicopathologic features. Cancer 110(12), 2785-2792 (2007).

43 Fischer JR, Ohnmacht U, Rieger N et al. Prognostic significance of RASSF1A promoter methylation on survival of nonsmall-cell lung cancer patients treated with gemcitabine. Lung Cancer 56(1), 115-123 (2007).

44 Grote HJ, Schmiemann V, Kiel S et al. Aberrant methylation of the adenomatous polyposis coli promoter $1 \mathrm{~A}$ in bronchial aspirates from patients with suspected lung cancer. Int. J. Cancer 110(5), 751-755 (2004).

45 Begum S, Brait M, Dasgupta S et al. An epigenetic marker panel for detection of lung cancer using cell-free serum DNA. Clin. Cancer Res. 17(13), 4494-4503 (2011).

46 Tang X, Khuri FR, Lee JJ et al. Hypermethylation of the death-associated protein (DAP) kinase promoter and aggressiveness in stage I non-small-cell lung cancer. J. Natl Cancer Inst. 92(18), 1511-1516 (2000).

47 Shivapurkar N, Gazdar AF. DNA methylation based biomarkers in noninvasive cancer screening. Curr. Mol. Med. 10, 123-132 (2010).

48 Kaneda A, Kaminishi M, Yanagihara K, Sugimura T, Ushijima T. Identification of silencing of nine genes in human gastric cancers. Cancer Res. 62, 6645-6650 (2002).

49 Miyamoto K, Asada K, Fukutomi T et al. Methylation-associated silencing of heparin sulphate D-glucosaminyl

3-O-sulfotransferase-2 (3-OST-2) in human breast, colon, lung and pancreatic cancers. Oncogene 22, 274-280 (2003).

50 Hagihara A, Miyamoto K, Futura J et al. Identification of $275^{\prime} \mathrm{CpG}$ islands aberrantly methylated and 13 genes silenced in human pancreatic cancers. Oncogene 23, 8705-8710 (2004).

51 Kaneda A, Takai D, Kaminishi M, Okochi E, Ushijima T. Methylation-sensitive representational difference analysis and its application to cancer research. Ann. NY Acad. Sci. 983, 131-141 (2003).

52 Ushijima T. Detection and interpretation of altered methylation patterns in cancer cells. Nat. Rev. Cancer 5, 223-231 (2005).

53 Herman JG, Graff JR, Myohanen S, Nelkin BD, Baylin SB. Methylation-specific PCR: a novel PCR assay for methylation status of CpG islands. Proc. Natl Acad. Sci. USA 93, 9821-9826 (1996).

54 Belinsky SA, Klinge DM, Dekker JD et al. Gene promoter methylation in plasma and sputum increases with lung cancer risk. Clin. Cancer Res. 11, 6505-6511 (2005).

55 Fraga MF, Esteller M. DNA methylation. A profile of methods and applications Biotechniques 33(632), 636-649 (2002).

56 Liloglou T, Bediaga NG, Brown BR, Field JK, Davies MP. Epigenetic biomarkers in lung cancer. Cancer Lett. doi:10.1016/j. canlet.2012.04.018 (2012) (Epub ahead of print).

57 Nikolaidis G, Raji OY, Markopoulou S et al. DNA methylation biomarkers offer improved diagnostic efficiency in lung cancer. Cancer Res. 72(22), 5692-5701 (2012).

58 Ostrow KL, Hoque MO, Loyo M et al. Molecular analysis of plasma DNA for the early detection of lung cancer by quantitative methylation-specific PCR. Clin Cancer Res. 16(13), 3463-3472 (2010).

59 Styles T, Grant V. Good Clinical Laboratory Practice. British Association of Research Quality Assurance, UK (2011).

60 Walter K, Holcomb T, Janmario T et al. DNA methylation Profiling defines clinically relevant biological subsets of non-small-cell lung cancer. Clin. Cancer Res. 18(8), 2360-2373 (2012).

61 Schuffler P, Mikeska T, Waha A, Lengauer T, Bock C. MethMarker: user-friendly design and optimization of nege-specific DNA methylation assays. Genome Biol. 10(10), R105 (2009).

62 Machida EO, Brock MV, Hooker CM et al. Hypermethylation of ASC/TMS1 is a sputum marker for late-stage lung cancer. Cancer Res. 66(12), 6210-6218 (2006). 
63 Leng S, Do K, Yingling CM et al. Define a gene promoter methylation signature in sputum for lung cancer risk assessment. Clin. Cancer Res. 18(12), 3387-3395 (2012).

64 De Fraipont F, Moro-Sibilot D, Michelland S, Brambilla E, Brambilla C, Favrot MC. Promoter methylation of genes in bronchial lavages: a market for early diagnosis of primary relapsing non-small-cell lung cancer? Lung Cancer 50 (2), 199-209 (2005).

65 Kim H, Kwon YM, Kim JS et al. Tumorspecific methylation in bronchial lavage for early detection of non-small-cell lung cancer. J. Clin. Oncol. 22(12), 2363-2370 (2004).

66 Dietrich D, Kneip C, Raji O et al. Performance evaluation of the DNA methylation biomarker SHOX2 for the aid in diagnosis of lung cancer based on the analysis of bronchial aspirates. Int. J. Oncol. 40(3), 825-832 (2012).

$67 \mathrm{Hu}$ YC, Sindrasky D, Ahrendt SA. Molecular detection approaches for smoking associated tumors. Oncogene 21(4), 7289-7297 (2002).

68 Simkin M, Abdalia M, El-Mogy M, HajAhmad Y. Differences in the quantify of DNA found in the urine and saliva of smokers versus nonsmokers: implications for the timing of epigenetic events. Epigenomics 4(3), 343-352 (2012).

69 Han W, Wang T, Reilly AA, Keller SM, Spivack SD. Gene promoter methylation assayed in exhaled breath, with differences in smokers and lung cancer patients. Respir. Res. 10, 86 (2009).

70 Li L, Choi JY, Lee KM. DNA methylation in peripheral blood: a potential biomarker for cancer molecular epidemiology. J. Epidemiol. 22(5), 384-394 (2012).

71 Levenson VV, Melnikov AA. DNA methylation as clinical useful biomarkers: light at the end of the tunel. Pharmaceuticals 5, 94-113 (2012).

72 Jen J, Wu L, Sindransky D. An overview on the isolation and analysis of circulating tumor DNA in plasma and serums. Ann. NYAcad. Sci. 906, 8-12 (2000).

73 Wang L, Aakre JA, Jiang R et al. Methylation markers for small cell lung cancer in peripheral blood leukocyte DNA. J. Thorac. Oncol. 5(6), 778-785 (2010).

74 Atamaniuk J, Ruzicka K, Stuhlmeier KM, Karimi A, Eigner M, Mueller MM. Cell-free plasma DNA: a marker for apoptosis during hemodialysis. Clin. Chem. 52(3), 523-526 (2006).

75 Chimonidou M, Strati A, Tzitzira A et al. DNA methylation of tumor suppressor and metastasis suppressor genes in circulating tumor cells. Clin Chem Res. 57(8), 1169-1177 (2011).
"- Original paper on DNA methylation markers detected in circulating tumor cells.

76 Board RE, Knight L, Greystoke A et al. DNA methylation in circulating tumor DNA as a biomarker for cancer. Biomark. Insights 2, 307-319 (2007).

77 Caseira Cabral RE, Cabral Neto JB, da Costa Carvalho MG. Circulating DNA as a biomarker for early detection of cancer: a brief update with an emphasis on lung cancer. Open Lung Cancer J. 3, 38-44 (2010).

78 Lee TH, Montalvo L, Chrebtow V, Busch MP. Quantitation of genomic DNA in plasma and serum samples: higher concentrations of genomic DNA found in serum than in plasma. Transfusion 41, 276-282 (2001).

79 Thijssen MA, Swinkels DW, Ruers TJ, de Kok JB. Difference between free circulating plasma and serum DNA in patients with colorectal liver metastases. Anticancer Res. 22, 421-425 (2002).

80 Liggett T, Melnikov A, Yi QL et al. Differential methylation of cell-free circulating DNA among patients with pancreatic cancer versus chronic pancreatitis. Cancer 116, 1674-1680 (2010).

81 Liggett TE, Melnikov A, Yi Q et al. Distinctive DNA methylation patterns of cell-free plasma DNA in women with malignant ovarian tumors. Gynecol. Oncol. 120, 113-120 (2011).

82 Kneip C, Schmidt B, Seegebarth A et al. SHOX2 DNA methylation is a biomarker for the diagnosis of lung cancer in plasma. J. Thorac. Oncol. 6(10), 1632-1638 (2011).

83 Esteller M, Sanchez-Cespedes M, Rosell R, Sidransky D, Baylin SB, Herman JG. Detection of aberrant promoter hypermethylation of tumor suppressor genes in serum DNA from non-small-cell lung cancer patients. Cancer Res. 59, 67-70 (1999).

84 Paliwal A, Vaissière T, Herceg Z. Quantitative detection of DNA methylation states in minute amounts of DNA from body fluids. Methods 52(3), 242-247. (2010).

85 Sterlacci W, Tzankov A, Veits L et al. A comprehensive analysis of p16 expression, gene status, and promoter hypermethylation in surgically resected non-small cell lung carcinomas. J. Thorac. Oncol. 6(10), 1649-1657 (2011).

86 Heller G, Zielinski CC, Zöchbauer-Müller S. Lung cancer: from single-gene methylation to methylome profiling. Cancer Metastasis Rev. 29(1), 95-107 (2010).

87 Topaloglu O, Hoque MO, Tokumaru Y et al. Detection of promoter hypermethylation of multiple genes in the tumor and bronchoalveolar lavage of patients with lung cancer. Clin. Cancer Res. 10, 2284-2288 (2004).

88 Geng J, Sun J, Lin Q et al. Methylation status of NEYROG2 and NID2 improves the diagnosis of stage I NSCLC. Oncol. Lett. 3(4), 901-906 (2012).

89 Schiemann V, Bocking A, Kazimirek M et al. Methylation assay for the diagnosis of lung cancer on bronchial aspirates: a cohort study. Clin. Cancer Res. 11, 7728-7734 (2005).

90 Grote HJ, Schiemann V, Geddert $\mathrm{H}$ et al. Methylation of RAS association domain family protein $1 \mathrm{~A}$ as a biomarker of lung cancer. Cancer 108, 129-134 (2006).

91 Fujii M, Fujimoto N, Hiraki A et al. Aberrant DNA methylation profile in pleural fluid for differential diagnosis of malignant pleural mesothelioma. Cancer Sci. 103(3), 510-514 (2012).

92 Van der Drift M, Prinsen C, Knuiman J, Janssen J, Dekhuijzen P.N, Thunnisen E. Diagnosis peripheral lung cancer: the additional value of RASSF1A methylation and KRAS mutation analyses in washings in non-diagnostic bronchoscopy. Chest 141(1), 169-175 (2012).

93 Schmidt B, Liebenberg V, Dietrich D et al. DNA methylation is a biomarker for the diagnosis of lung cancer based on bronchial aspirates. BMC Cancer 10, 600 (2010).

94 Lu F, Zhang HT. DNA Methylation and non-small-cell lung cancer. Anat. Rec. 94, 1787-1795 (2011).

95 Brock MV, Hooker CM, Ota-Machida E et al. DNA methylation markers and early recurrence in stage I lung cancer. $N$. Engl. J. Med. 358, 1118-1128 (2008).

96 Yamamoto H, Toyooka S, Mitsudomi T. Impact of EGFR mutation analysis in nonsmall-cell lung cancer. Lung Cancer 63, 315-321 (2009).

97 Zhang Y, Wang H, Song G et al. Methylation of multiple genes as a candidate biomarker in non-small-cell lung cancer. Cancer Lett. 303 21-28 (2011).

98 Yang J, Shen Y, Liu B, Tong Y. Promoter methylation of BRMS1 correlates with smoking history and poor survival in nonsmall cell lung cancer patients. Lung Cancer 74, 305-309 (2011).

- - Study on a very promising novel prognostic marker.

99 Lokk K, Vooder T, Kolde R et al. Methylation markers of early-stage nonsmall-cell lung cancer. PLoS One 7(6), e39813 (2012).

100 Dietrich D, Hasinger O, Liebenberg V, Field JK, Kristiansen G, Soltermann A. DNA methylation of the homeobox genes PITX2 
and $S H O X 2$ predicts outcome in non-smallcell lung cancer patients. Diagn. Mol. Pathol. 21, 93-104 (2012).

101 Bartel DP. MicroRNAs: genomics, biogenesis, mechanism, and functions. Cell 116, 281-297 (2004).

102 Lee RC, Feinbaum RL, Ambros V. The C. elegans heterochronic gene lin -4 encodes small RNAs with antisense complementarity to lin-14. Cell 75, 843-854 (1993).

103 Esquela-Kerscher A, Slack FJ. Oncomirs microRNAs with a role in cancer. Nat. Rev. Cancer 6, 259-269 (2006).

104 He L, Hannon GJ. MicroRNAs: small RNAs with a big role in gene regulation. Nat. Rev. Genet. 5, 522-531 (2004).

105 He L, He X, Lowe SW, Hannon GJ. MicroRNAs join the p53 network-another piece in the tumour-suppression puzzle. Nat. Rev. Cancer 7, 819-822 (2007).

106 Cho WC. OncomiRs. The discovery and progress of microRNAs in cancers. Mol. Cancer 6, 60 (2007).

107 Hwang HW, Mendell JT. MicroRNAs in cell proliferation, cell death and tumorigenesis. $\mathrm{Br}$. J. Cancer 94(6), 776-780 (2006).

108 Hebert C, Norris K, Scheper MA et al. High mobility group A2 is a target for miRNA-98 in head and neck squamous cell carcinoma. Mol. Cancer 6(5) (2007).
109 Calin GA, Croce CM. MicroRNA signatures in human cancers. Nat. Rev. Cancer 6, 857-866 (2006).

110 Takamizawa J, Konishi H, Yanagisawa K et al. Reduced expression of the let-7 microRNAs in human lung cancers in association with shortened postoperative survival. Cancer Res. 64, 3753-3756 (2004).

111 Johnson SM, Grosshans H, Shingara J et al. RAS is regulated by the let-7 microRNA family. Cell 120, 635-647 (2005).

112 Johnson CD, Esquela-Kerscher A, Stefani G et al. The let-7 microRNA represses cell profileration pathways in human cells. Cancer Res. 67, 7713-7722 (2007).

113 Wang X, Ling C, Bai Y, Zhao J. MicroRNA-206 is associated with the invasion and metastasis of lung cancer. Anat. Rec. 294, 88-92 (2011).

114 Hayashita Y, Osada H, Tatematsu Y et al. A polycistronic microRNA cluster, miR-17-92 is overexpressed in human lung cancers and enhances cell proliferation. Cancer Res. 65, 9628-9632 (2005).

115 Heller G, Weinzierl M, Noll C et al. Genomewide miRNA expression profiling identifies $m i R-9-3$ and $m i R-193 a$ as targets for DNA methylation in non-small cell lung cancers. Clin. Cancer Res. 18(6), 1619-1629 (2012).

116 Fazi F, Racanicchi S, Zardo G et al. Epigenetic silencing of the myelopoiesis regulator microRNA-223 by the AML1/ETO oncoprotein. Cancer Cell 12, 457-466 (2007).

117 Lujambio A, Ropero S, Ballestar E et al. Genetic unmasking of an epigenetically silencing microRNA in human cancer cells. Cancer Res. 67, 1424-1429 (2007).

118 Bueno MJ, Perez de Castro I, Gomez de Cedron $\mathrm{M}$ et al. Genetic and epigenetic silencing of microRNA-203 enchances ABL1 and BCR-ABL1 oncogene expression. Cancer Cell 13, 496-506 (2008).

119 Brueckner B, Srtesemann C, Kuner R et al. The human let-7a-3 locus contains an epigenetically regulated microRNA gene with oncogenic function. Cancer Res. 67, 1419-1423 (2007).

120 Fabbri M, Garzon R, Cimmino A et al. MicroRNA-29 family reverts aberrant methylation in lung cancer by targeting DNA methyltransferases EA and 3B. Proc. Natl Acad. Sci. USA 104, 15805-15810 (2007).

121 Heyn H, Esteller M. DNA methylation profiling in the clinic: applications and challenges. Nat. Rev. Genet. 13(10), 679-692 (2012).

"- Highlights the clinical value of the epigenetic profile in cancer.

122 Li KK, Li F, Li QS, Yang K, Jin B. DNA methylation as a target of epigenetic therapeutics in cancer. Anticancer Agents Med. Chem. (2012) (Epub ahead of print). 